\title{
Pretoria intervention saves E Cape health corruption-buster
}

Progressivedisempowerment and provincial healthcare under-budgeting in the Eastern Cape almost forced the resignation of its corruption-buster chief, Dr Siva Pillay and his most trusted administrators last month. The political moves were directly responsible for thousands of healthcare workers going without pay or being underpaid, for five months.

National health minister, $\mathrm{Dr}$ Aaron Motsoaledi, who head-hunted Pillay, and ANC Secretary General, Gwede Mantashe, intervened on the eve of a two-week resignation deadline Pillay and Eastern Cape Premier Noxolo Kieviet had agreed upon to try and resolve an internal deadlock.

Pillay, a former national parliamentarian and his political head, Eastern Cape Health MEC, Sicelo Gqobana, went head to head in a protracted power struggle that undermined service delivery, each accusing the other of 'sabotage', resulting in Pillay threatening to resign on 15 June unless he was given back administrative control - progressively bled from him over the last six months.

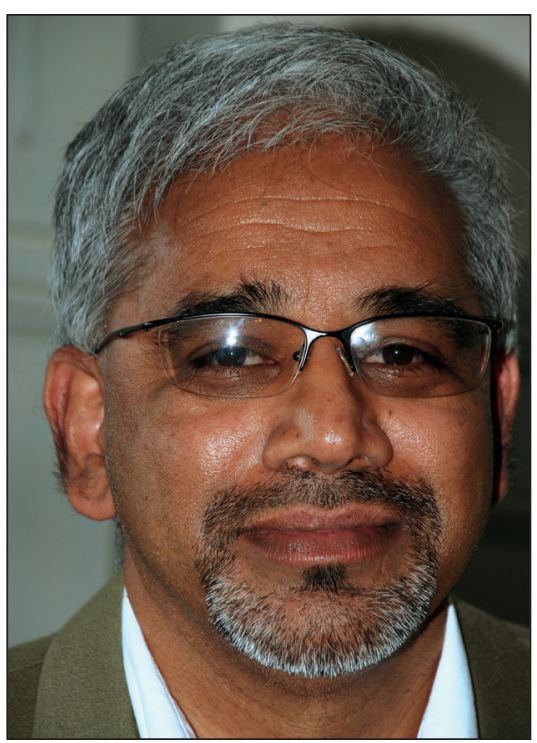

Dr Siva Pillay, Director General of Health, Eastern Cape.

The South African Medical Association (SAMA) weighed in with an urgent court interdict demanding that all unpaid and underpaid doctors be immediately recompensed and that a moratorium on appointing new doctors be lifted. SAMA demanded that the health department be placed under full national administration to address what it said amounted to a dire management and healthcare-delivery crisis. This comes in spite of Pretoria this April having chosen to pilot a programme for proper procurement and monitoring by embedding in Pillay's department a high-tech national multi-agency work group, including the Hawks, Asset Forfeiture Unit and National Treasury. ${ }^{1}$ Proponents of the intervention boasted to Izindaba that it would cut fraud and wastage by up to $80 \%$. Many of its members grew disenchanted and saw the in-fighting as white-anting their state-of-the-art anticorruption and service delivery initiatives - but the national political intervention has now strengthened their hand.

Their intercession was inspired by Pillay's prior clean-up of a corruption hi-jacked department over the previous two years during which he fired or forced the resignation of more than 1200 people, mostly health department administrative staff - some of them in pivotal senior infrastructure or finance positions where hundreds of millions of Rand were being pilfered annually. Several of the sacked top officials with provincial cabinet-level connections have since been waging a political campaign against him which at one stage led to a cabinet-ordered but ultimately baseless forensic enquiry ${ }^{2}$

Ominous warning nearly played out Pillay was physically threatened by a silent gun-toting man in the deserted car park below his Bhisho offices around $9 \mathrm{pm}$ on 25 January last year,3 releasing his two trained alsatians which chased the would-be assailant back into a waiting BMW which sped away, and verbally threatened by the husband of his sacked chief financial officer at the provincial legislature last April. $\mathrm{He}$ said the verbal threat included the man telling him: 'Don't forget this is Bhisho and some of what you sow, you shall reap. $\mathrm{He}$ told me the pit they were digging for me was getting deeper and deeper and when they buried me, nobody would ever get me out.'

From November last year Pillay's three core functions as health director general were shifted beyond his control (in all of which he made decisive changes which saved hundreds of millions of Rand and uncovered corruption). First his air and land ambulance rescue services were moved to the Transport Department, then provincial cabinet set up a Health Infrastructure Management Committee under Premier Kieviet, and finally the Human Resources for Health function, including PERSAL (the salary management system) was moved to the provincial treasury, resulting in 4000 healthcare workers, including scores of doctors, going unpaid for five months. In a meeting with SAMA's angry public sector committee on 4 June, Health MEC Gqobana apologised profusely, vowing to donate his own salary should the few outstanding unpaid doctor salaries, bulk unpaid rural allowances and commuted overtime not quickly reach the doctors, whose daily living expenses were supplemented by colleagues and SAMA.

\section{Budget hammer blow}

Another blow to Pillay was via his provincial budget allocation, which many experts in the NGO, Section 27 and SAMA suspect was consciously and illegally set low. From inheriting a 2.8 billion deficit when he came in two years ago, Pillay was allocated R600 million in his first year and R700 million in his second - effectively a $2.7 \%$ decrease where every other department (except Transport) was given increases, some of them substantial. From January this year (when he was no longer in control of the healthcare PERSAL), the salaries of 4000 healthcare workers were either underpaid or not paid, including 67 doctors (at least 47 of whom are permanent and the rest sessional). This led to a lunchtime doctor picket at the Nelson Mandela Academic Hospital in Mthatha, a mass meeting and an aborted SAMA march on the Bhisho administrative headquarters.

\section{Pillay admitted to Izindaba that the doctor non-payment was a huge embarrassment but without the PERSAL function, no deputy director generals for clinical services, human resources and no chief financial officer, 'it's a recipe for failure to tell me to fix it.'}

\section{Ineptitude aggravated workers}

One former Pillay insider told Izindaba that the provincial Treasury had so little hands-on experience of healthcare worker payment that it had both incorrectly 'captured' doctors in new posts and, instead of the negotiated $22 \%$ rural allowance, paid them a mere R22.00 
each, adding fuel to the collective fire. By the time of going to press most of the doctors had been paid and SAMA had withdrawn its interdict. Pillay admitted to Izindaba that the doctor non-payment was a huge embarrassment but without the PERSAL function, no deputy director generals for clinical services, human resources and no chief financial officer, 'it's a recipe for failure to tell me to fix it.' A new internal task team, consisting of the Premier, Pillay's department, his MEC and Provincial Treasury will in future co-ordinate and monitor all planning with the premier agreeing to reign in Pillay and Gqobana should they deviate from agreed-upon goals and strategies.

It was reliably learnt that agreement was reached on critical areas which include provincial Treasury taking responsibility for all procurement tenders put out by the national Multi Agency Work Group, human resource under-budgeting (a revised organogram on posts and equitable distribution of healthcare staff, audited monthly), an overhaul of administrative procedures in disciplining and firing of staff (a major bone of contention between Gqobana, whom the unions ran to, and Pillay), function-based funding for the rationalised service delivery platform (a pet cost-saving project of Pillay's) and addressing a 'discordance' between human resource development and primary healthcare delivery. One of the first agreedupon tasks of the new leadership team will be to advertise effectively for the pivotal empty senior posts in Pillay's department.

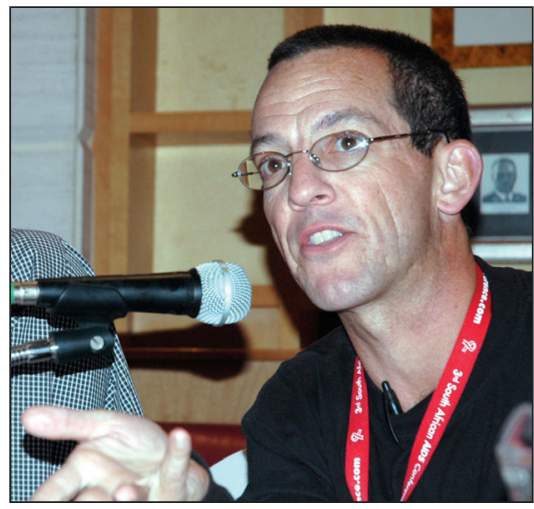

Mark Heywood, Director of Section 27.

Mark Heywood, Director of Section 27 (including the Treatment Action Campaign (TAC)), had harsh words for what he saw as the political undermining of a health chief intent on tackling a collapsing, sleazy health administration. 'It's been coming for a long time. I think the final straw for him was the doctors threatening to strike and many who don't know the truth holding him personally accountable. This is not about delivery, honesty, integrity and efficiency the issues which ought to guide who serves and who falls in the health system; it's about good people getting squashed, and corrupt and inefficient people holding (on to) their positions. The people who pay for that ultimately are the users of the health system.

This is not about delivery, honesty, integrity and efficiency - the issues which ought to guide who serves and who falls in the health system; it's about good people getting squashed, and corrupt and inefficient people holding (on to) their positions.

A sign of things to come for the NHI? Speaking when Pillay's resignation seemed inevitable, Heywood said that if Motsoaledi and Kieviet were not given complete free reign to deal with this (which he regards as a key test of political ability to back clean, more efficient administration), 'you can wave National Health Insurance (NHI) goodbye. The consequences of this to the health system will be as serious as AIDS denialism ever was. The NHI simply has to be built on a strengthening public health system not on a collapsing one'. Izindaba reliably learnt that Pillay's department negotiated an overdraft with provincial treasury to cover accruals and the R2.8 billion overdraft which Treasury allegedly reneged on. The funding of the R1.51 billion capital was managed through 'top-slicing' (repayment by Treasury prior to disbursement to the health department) - meaning that repayment was made against a capital contribution the health department did not have. Heywood said that 'at the very minimum' the top sliced amounts (related to the overdraft) needed to be restored while crucial unfunded mandate issues needed redress. Negative growth in a budget was legally impermissible, let alone morally outrageous in a health context. Any future turnaround plan would only be effective if weaknesses in critical systems such as human resources and supply chain management were identified and fixed and endemic corruption eradicated, he added.

Dr Pophi Ramathuba, chairperson of SAMA's public sector committee, said 'the biggest mistake' was to appoint Pillay (also a member of the national Communist Party executive) as head of department instead of as a member of the provincial cabinet (Health MEC), with real political leverage. 'At the end of the day the relationship between him and his political head became dysfunctional - and we suffered. He was seen as undermining the politicians and they had to hit back. It seems he did not listen when they told him what to do. So they dealt with him and took away the PERSAL. That crippled him. They showed him that he's not the politician; they are. He was basically seen as too close to the Premier and not recognising the Health MEC.'

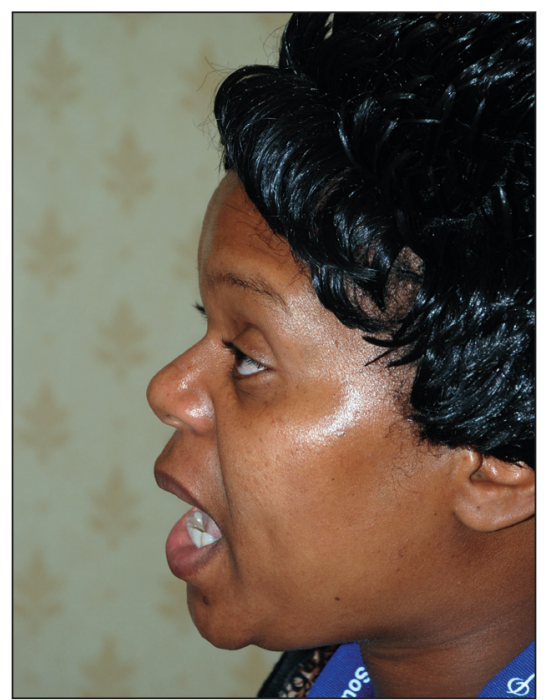

Dr Pophi Ramathuba, Chairperson of SAMA's Public Sector Committee.

It seems he did not listen when they told him what to do. So they dealt with him and took away the PERSAL. That crippled him. They showed him that he's not the politician; they are. He was basically seen as too close to the Premier and not recognising the Health MEC.'

SAMA's acting chairman, Dr Mark Sonderup, said it was 'particularly disturbing that this issue (non-payment) has now arisen after the recent criticisms levelled at doctors by the department for allegedly not wanting to work in the province. We strongly condemn the chaos that resulted.' Ramathuba said the most chronic selfinflicted injury of the department would be newly qualified interns putting any Eastern Cape post as their last choice for community service this July, and all other qualified healthcare workers avoiding what appeared to be a dysfunctional and obdurate Eastern Cape public health sector in future.

\section{Chris Bateman}

chrisb@hmpg.co.za

1. Bateman C. Bhisho corruption busting now the national pilot. S Afr Med J 2012:102:274-276.

2. Bateman C. E Cape health chief hits back at 'jobs for pals' charges. S Afr Med J 2011;101:610-612.

3. Bateman C. Corruption busting a real health threat. S Afr Med J 2011;101:360-363. 